\title{
Urban Growth Structure and Travel Behavior in Tehran City
}

\author{
Mahmood Shoorcheh ${ }^{1}$, Hamidreza Varesi ${ }^{1}$ Jamal Mohammadi $^{1} \&$ Todd Litman ${ }^{2}$ \\ ${ }^{1}$ Department of Geography and Planning Sciences, University of Isfahan, Isfahan, Iran \\ ${ }^{2}$ Victoria Transport Policy Institute, British Colombia, Canada \\ Correspondence: Mahmood Shoorcheh, Department of Geography and Planning Sciences, University of Isfahan, \\ Isfahan, Iran., PO BOX 81746-73441 Isfahan, Iran. Tel: 98-31-379-33081. E-mail: \\ mahmood.shoorcheh@gmail.com
}

Received: April 2, 2016

doi:10.5539/mas.v10n8p32
Accepted: April 16, 2016

Online Published: June 5, 2016

\begin{abstract}
This paper investigates major characteristics of Tehran's urban growth structure, how various land use factors such as "density", "diversity", "design" and "accessibility" affect travel behavior, population growth and land use development, and future travel demands. Tehran city is currently developing in ways that are likely to increase sprawl and automobile-dependency, which increase problems including traffic and parking congestion, consumer costs, traffic accidents, pollution emissions and inadequate mobility for non-drivers. This analysis indicates that the growth management policies in Tehran's Comprehensive Plan can significantly reduce vehicle travel and associated problems, resulting in a more sustainable urban development path. This information is useful for evaluating the ability of policies such as Smart Growth, New Urbanism and Accessibility Management to help achieve transport-land use planning objectives.
\end{abstract}

Keywords: urban growth, land use, transport, Vehicle Miles Traveled (VMT), Tehran City

\section{Introduction}

Today, most urban residents frequently travel from their residential neighborhood to other areas for activities such as shopping, work and recreation. As a result, transport systems and land-use systems interact in many ways (Black, 2003; Hanson and Giuliano 2004; Rodrigue et al., 2006).

Until the early twentieth century, most cities, including Tehran city, developed in the form of compact and mixed use neighborhoods where most commonly-used services were located within walking distance of homes. However, increased motor vehicle travel significantly changed this urban development pattern. After the World War II and modernization in Iran, due to the rapid growth of using automobiles and following modern land use regulations, a new urban development pattern together with the significant growth of cities became widespread in this country (Farnaz Arefian \& Iradj Moeini, 2016). Today, this kind of pattern is called "urban sprawl" which encourages and intensifies spatial separations of different locations for activities and increases private automobile use (Frumkin et al. 2004; Bruegmann, 2005; Morris, 2005; Burchell et al., 2005; Bhatta, 2010; Williamson, 2010).

From 1970s on, many planning experts, particularly in Europe and North America, began supporting and theorizing new approaches of urban design and planning in order to help reduce negative influences (including traffic congestion, air pollution and urban sprawl) of using automobiles in a widespread manner (Keats, 1958; Mumford, 1964; Leavitt, 1970; Mitchell, 1970; Schneider, 1972; Buel, 1972). Their basic idea is to encourage more compact and integrated urban development, so non-motorized transportation (also known as "Active Transportation" and "Human Powered Transportation") and public transportation could serve a greater portion of trips. Such approaches are now known as "Compact Cities," "New Urbanism," "Transit Oriented Development" and "Smart Growth" (Jacobs, 1961; Kunstler, 1993; Calthorpe, 1993; Jenks and Burgess, 2000; Duany and et al., 2000; Calthorpe and Fulton, 2001; Hayden, 2003; Talen, 2005; Grant, 2006). They all reflect same basic idea: land development patterns affect people's travel behaviors, and as a result, changing travel patterns can help reduce many of the problems resulting from motor vehicle traffic.

\section{Problem Definition}

Tehran City's current policies result dispersed and automobile dependent development. As extensively explored 
in scholarly research, sprawl and automobile-based planning causes a variety of economic, social and environmental problems as summarized in Table 1.

Table 1. Costs of Sprawl and Automobile Dependency

\begin{tabular}{lll}
\hline Economic & Social & Environmental \\
\hline Increased costs of providing public & Reduced accessibility and & Open-space (farmland and wildlife habitat) \\
infrastructure and services & economic opportunity for & displacement \\
Increased consumer transportation & non-drivers & Increased noise, air and water pollution \\
costs (households must pay more for & Increased traffic casualties & emissions \\
vehicles, fuel and taxi fares) & Reduced public fitness & Increased energy consumption \\
Increased road and parking facility & and health (due to less & Heat island effects (more solar gain) \\
costs & exercise) & Increased hydrologic disruptions, \\
Increased traffic congestion & Reduced chauffeuring & including, higher storm-water management \\
Reduced economic productivity & burdens on motorists & costs, and reduced groundwater recharge \\
\hline
\end{tabular}

Source: Burchell, et al., 2005; Litman, 2014

\section{Aims and Research Questions}

This article is motivated by an attempt to analyze urban growth structure as a tool for controlling land use expansion and accessibility-based planning in the Tehran city. Our investigation intends to deal with many of the land use and transportation factors, which still appear to be underrepresented in growth management research in the Tehran.

The article is based on the following main objectives:

- Characterizing the urban growth structure in the Tehran and analyzing the urban growth aspects in the land use and transportation.

- $\quad$ Estimate of urban growth quality.

- Survey of public values and attitudes about car use/ownership, travel mode choice and Preferences for living in smart or sprawl neighborhoods.

- $\quad$ Measuring of land use factors impacts on Vehicle Miles Traveled (VMT) for Tehran city.

\section{A Brief Review of Literature}

Land use and transport development is best understood as a product of socio-economic development. The complexity of this connection has undergone great shifts, since it is determined by local, regional, state, nationwide, and even global issues.

Following the pioneering classical urban micro-economic theories of Ricardo (1821), Von Thunen(1826), Wingo(1961), Alonso(1964) and Lowry(1964), among others, that provide the standard reference point to understanding the relationship between land use and transportation, other researchs done on Land Use-Transport Interaction (LUTI) and their modeling has attracted much interest (Boyce et al. 1981; Landis 1992; Simmonds, 2001; Miller et al. 1998; Anderstig and Mattsson 1991; Putman, 1983/1991; Kim, 1989; Mackett 1991; Hunt and Echenique, 1993; Williams, 1994; Anas, 1998; Martinez, 1996; Hunt and Abraham, 2003; Caindec and Prastacos, 1995; Miyamoto and Udomsri, 1996; Haag,1990; ODOT, 2002; de la Barra, 1989; Hensher and Ton 2001; Waddell, 2002; Mackett, 1983/1990; Wilson, 1997; Anderstig and Mattsson 1998; Webster et al. 1988; Wegener and Fürst 1999; Albeverio, 2008; Allen, 1997; Batty, 2007, 2008; Ewing and Cervero, 2010; Samet, 2013; Coppola et al., 2013; Acheampong and Silva, 2015).

After the domination of "sustainability" talks in urban studies and planning, new regulations in transport and air pollution have caused significant effects on policy decisions made in land use and urban sustainable development achievements (VTPI, 2005; Department for Transport, 2007; Schiller et al. 2010; Black, 2010; Bauer, 2010; SUMP, 2013; Taniguchi, 2015; Gudmundsson et al. 2016; www.epa.gov). One of the reasons that LUTI has attracted planners, designers, transport engineers and geographers is that both transportation and land use policies absorb significant investments, which can have key influences on urban development patterns' change and evolution. 
Table 2. Approaches, Theories and concepts in Land use-transport interaction modeling

\begin{tabular}{|c|c|c|c|c|c|c|}
\hline Approaches & $\begin{array}{l}\text { gravity/spatial } \\
\text { interaction } \\
\text { approach } \\
\end{array}$ & $\begin{array}{l}\text { economic } \\
\text { approach }\end{array}$ & $\begin{array}{l}\text { social science } \\
\text { approaches }\end{array}$ & $\begin{array}{l}\text { behavioral } \\
\text { approach }\end{array}$ & $\begin{array}{l}\text { design } \\
\text { approach }\end{array}$ & $\begin{array}{l}\text { Complexity } \\
\text { systems } \\
\text { approach }\end{array}$ \\
\hline Theories & $\begin{array}{l}\text { theory of social } \\
\text { physics }\end{array}$ & $\begin{array}{l}\text { classical urban } \\
\text { micro-economic } \\
\text { theories }\end{array}$ & $\begin{array}{l}\text { Chicago school; } \\
\text { time-geography }\end{array}$ & $\begin{array}{l}\text { theories of } \\
\text { decision } \\
\text { making }\end{array}$ & $\begin{array}{l}\text { traditional } \\
\text { and new- } \\
\text { Traditional } \\
\text { theories } \\
\end{array}$ & $\begin{array}{l}\text { Complexity } \\
\text { theory }\end{array}$ \\
\hline Concepts & $\begin{array}{l}\text { (social physics; } \\
\text { Newtonian } \\
\text { concept of } \\
\text { gravity; } \\
\text { entropy } \\
\text { maximization) }\end{array}$ & $\begin{array}{l}\text { (microeconomic; } \\
\text { concept of utility } \\
\text { maximization; } \\
\text { market } \\
\text { equilibrium) }\end{array}$ & $\begin{array}{l}\text { (transportation } \\
\text { technology; } \\
\text { social filtering } \\
\text { process between } \\
\text { different income } \\
\text { groups; Time } \\
\text { geography; } \\
\text { effects of ICTs } \\
\text { on activity and } \\
\text { travel patterns; } \\
\text { space-time } \\
\text { accessibility) }\end{array}$ & $\begin{array}{l}\text { (individual } \\
\text { choice } \\
\text { decisions; } \\
\text { behavioral } \\
\text { foundations } \\
\text { of } \\
\text { mathematic } \\
\text { models or } \\
\text { computer } \\
\text { simulation } \\
\text { models; } \\
\text { threshold } \\
\text { rule) }\end{array}$ & $\begin{array}{l}\text { (hierarchy; } \\
\text { morphology; } \\
\text { layers; } \\
\text { architecture) }\end{array}$ & $\begin{array}{l}\text { (disequilibrium; } \\
\text { adaptive } \\
\text { systems; } \\
\text { nonlinear, } \\
\text { self-organizing, } \\
\text { synergetic; } \\
\text { fractal geometry; } \\
\text { chaos) }\end{array}$ \\
\hline
\end{tabular}

Source: Authors' work.

However, existing LUTI models are unable to forecast the impact of future urban-policy responses, accessibility impacts land values and shapes the location behavior of households and firms, which in turns impacts observed patterns of spatial interactions. Thus, to adequately assess and evaluate the long-term impacts of investment and policies affecting land use on transport and vice versa, a more robust methodology is needed for deriving accessibility indices as the feedback mechanism of the land-use-transport link. (Wegener 2011in Acheampong and Silva, 2015: 27-28). The potential impacts of individual lifestyles and preferences are another important aspect that taken into consideration in this study.

Hence, this article discusses the key components that have constituted the focus of LUTI research and operational model development based on a conceptual framework shown in Figure 1. As shown in the conceptual framework, travel behavior is influenced by urban growth structure via accessibility, travel demand and dwelling demand factors as well as cognitive factors such as attitudes, preferences, perception, etc.

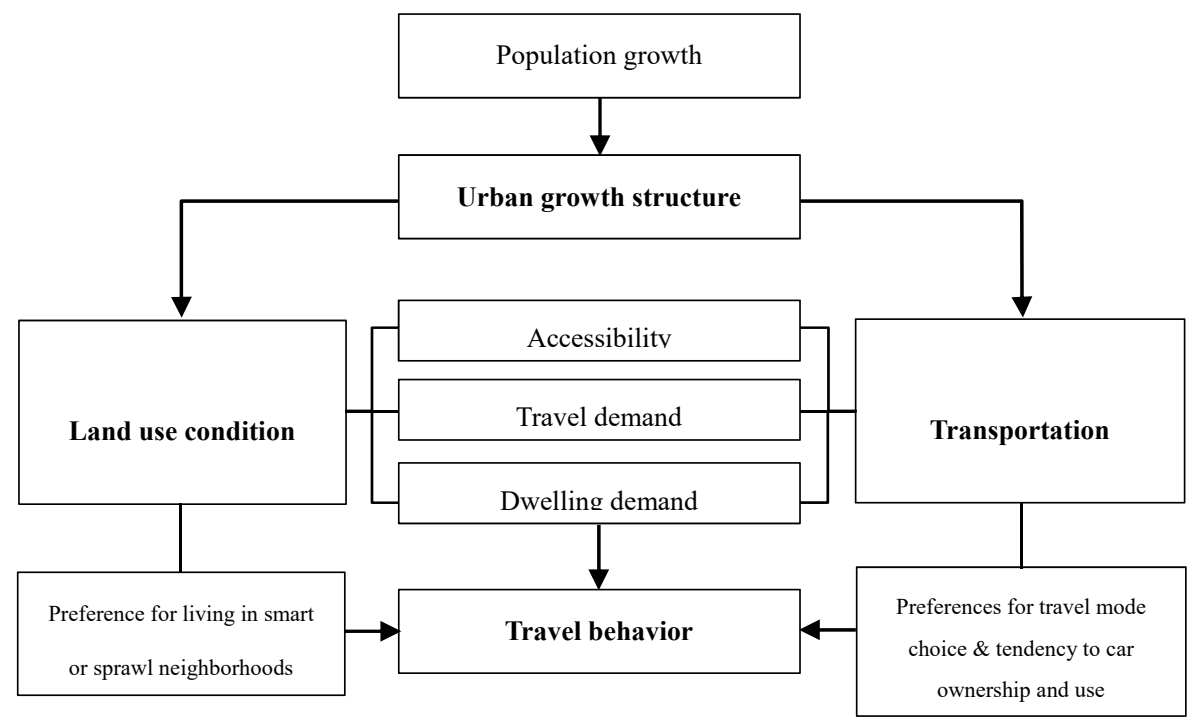

Figure 1. Conceptual framework of relation between urban growth structure and travel behavior

Source: Authors' work 


\section{Materials and Methods}

In this research, a case study method has been used to achieve the objectives. The case study as a research method can include various techniques. Among methods, we used a questioner to survey attitudes and preferences from people in the area. In addition, secondary data were used throughout the whole study by using SPSS Statistical Software and spatial/geographical distribution models such as Gini coefficient, Entropy coefficient, Shannon entropy, Holdren model and TOD index (TOD index method in this study suggested by authors base on Gini coefficient rationality). These data were collected at "Iran Statistics Center", "Tehran Municipality's Comprehensive Plan" and "Tehran Comprehensive Transportation and Traffic Company".

\section{Study Area and Location}

Tehran is the largest metropolitan in Iran and serves as a capital city of the country. It has 22 urban districts and each district has its own municipality, all of which work under the head municipality (Figure 2).
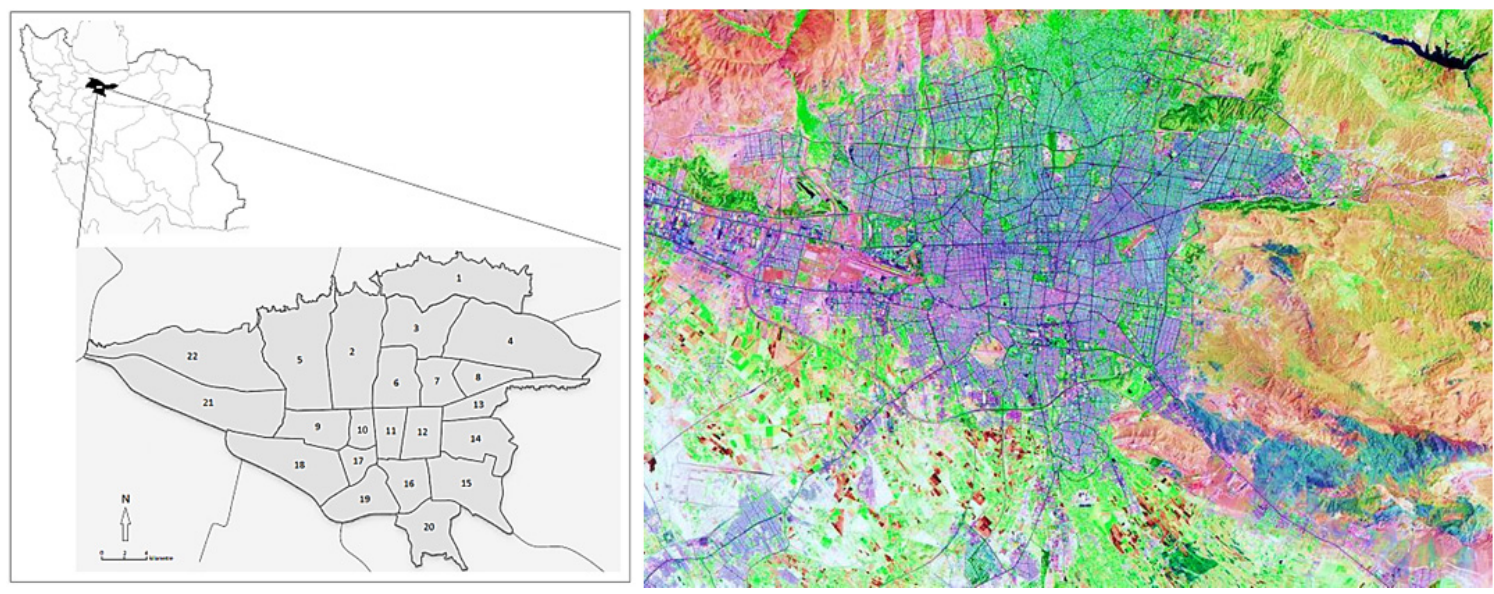

Figure 2. Geographical location of Tehran and it's Characteristics from up

Source: Authors' work (left); Tehran Comprehensive Transportation and Traffic Co. http://trafficstudy.tehran.ir (right)

\section{Urban Growth Conditions}

\subsection{Population}

Urban growth is most directly determined by a growing population. Since 1926 to 2015 , its population has always had an ascending trend due to modernization, centralization and domestic immigrations in such a manner that the figure has reached from 250 thousands to 8.7 millions in the 90 -year period (http://salnameh.sci.org.ir) (Figure 3).

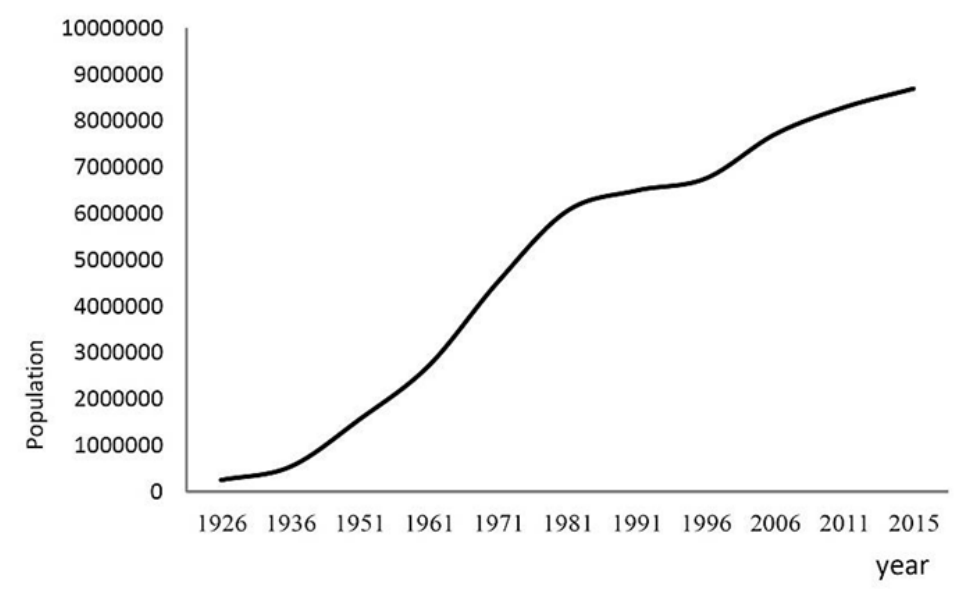

Figure 3. Trend of population increasing in Tehran from 1926 to 2015

Data source: Statistical Center of Iran. http://www.amar.org.ir/english 


\subsection{Mobility Condition}

Urban growth and land use patterns affect accessibility (people's ability to reach desired services and activities), which affects mobility (the amount and type of travel activity). Automobile ownership per capita is 0.38 cars per urban resident. More than 4.5 million automobiles and more than 3 million motorcycles operate in Tehran. On daily basis, about 10.3 million liters of gasoline, 3.9 million liters of gas oil and 1.3 million cubic meters of CNG are consumed in the city. The highest share of motor vehicles in urban daily travels belongs to automobiles (private cars) and the rate of inner-city trips is increasingly augmenting (Tehran Comprehensive Transportation and Traffic Co., 2015).

In the current years, the number of daily trips has increased from 14 million to nearly 18 million in the metropolitan region. This results in part from the increase in the distance between origins and destinations, as well as increase in automobile ownership rate. In other words, land use-transport policies have mostly focused on "mobility" rather than "accessibility" (Figure 4).

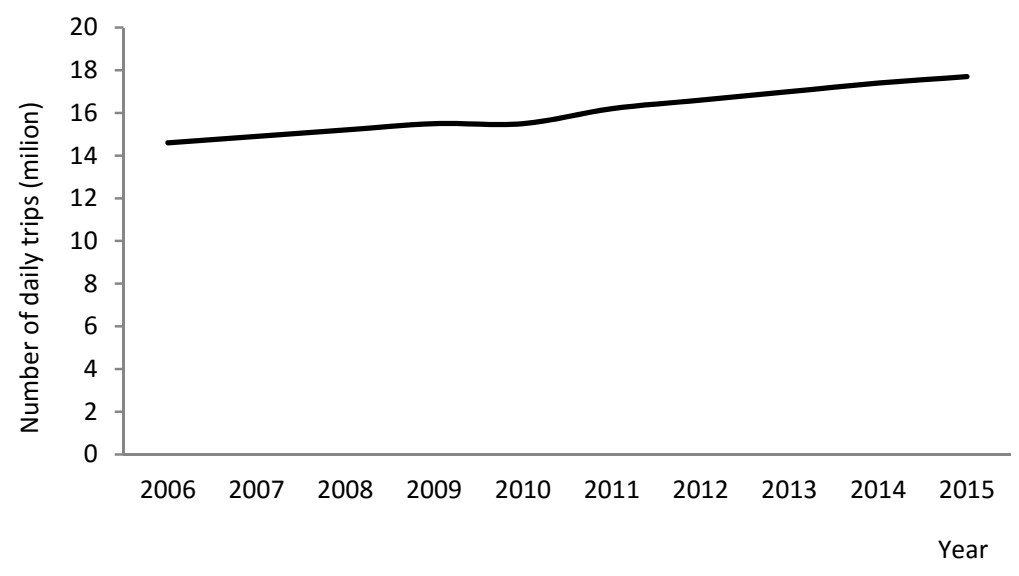

Figure 4. Trend of changes in Tehran's daily trips from 2006 to 2015

Data source: Tehran Comprehensive Transportation and Traffic Co. http://trafficstudy.tehran.ir

\subsection{Modes of transportation}

Most development from 1950 and 2015 was automobile dependent, designed primarily for automobile access with little consideration for other modes (Figure 5 and Figure 6). Then, the statistic data related to the share of vehicles in daily trips in Tehran shows that the highest figure belongs to private cars (44\%) and after that to taxi cabs $(22 \%)$, revealing the fact that the main mode of transportation is motor-based and the dominant pattern of urban growth is vehicle-based (Figure 7 and Figure 8).

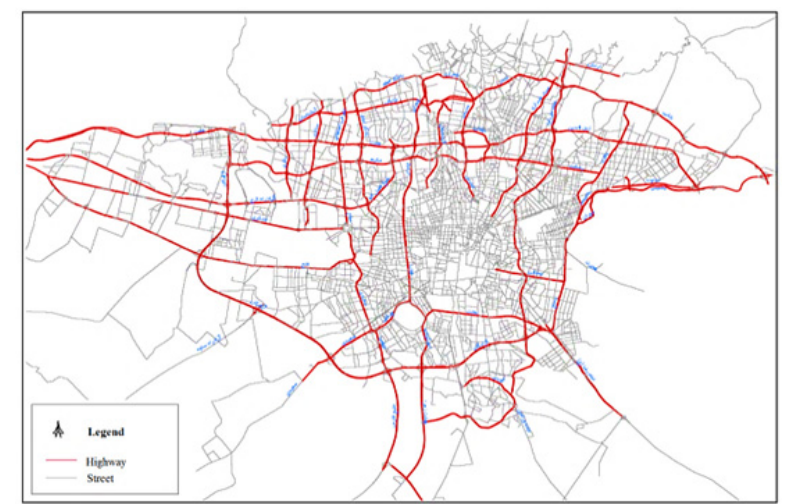

Figure 5. Highway and Street network

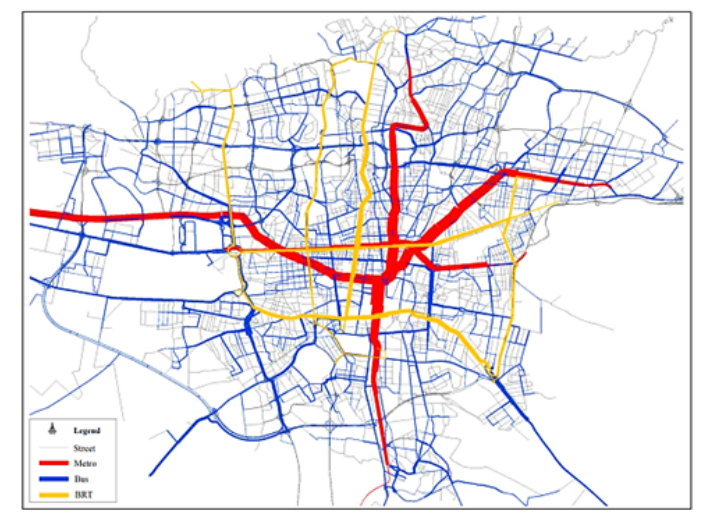

Figure 6: Street, Metro, Bus and BRT network

Source: Tehran Comprehensive Transportation and Traffic Co. http://trafficstudy.tehran.ir 
The share different vehicles has in traffic congestion reveals that private cars have the most influence on traffic congestion in such a way that they cause $65.5 \%$ of urban traffic congestion. After private cars, different types of taxi cabs create $20 \%$ of urban traffic congestion.

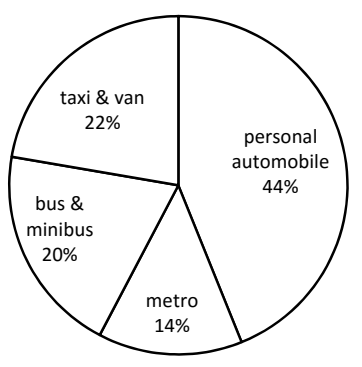

Figure 7. Share of vehicles in traffic production

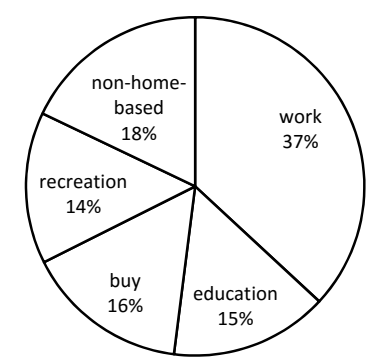

Figure 8: daily trips by modes of transportation

Data source: Tehran Comprehensive Transportation and Traffic Co. http://trafficstudy.tehran.ir

\subsection{Automobile-Dependency}

The development of the highway system and car ownership/use, which were driven by municipal regulations, has been a great influence on growth structure. Pearson Correlation among variables including motor vehicle ownership, parking area, motor transportation network area, time of trips and speed of trips totally indicates significant correlation, meaning that the pattern of land use-transport development in all districts has moved along the condition of automobile dependency (Table 3).

Table 3. Correlations between automobile-dependency variables in Tehran regions

\begin{tabular}{|c|c|c|c|c|c|c|}
\hline & & $\begin{array}{l}\text { Motor vehicle } \\
\text { ownership }\end{array}$ & $\begin{array}{l}\text { Parking } \\
\text { area }\end{array}$ & $\begin{array}{l}\text { Motorized transport } \\
\text { networks area }\end{array}$ & $\begin{array}{l}\text { Trips } \\
\text { time }\end{array}$ & $\begin{array}{l}\text { Trips } \\
\text { speed }\end{array}$ \\
\hline \multirow{3}{*}{$\begin{array}{l}\text { Motor vehicle } \\
\text { ownership }\end{array}$} & $\begin{array}{l}\text { Pearson } \\
\text { Correlation }\end{array}$ & 1 & .354 & $.812^{* *}$ & $.647^{* *}$ & $.716^{* *}$ \\
\hline & Sig. (2-tailed) & & 106 & .000 & .001 & .000 \\
\hline & $\mathrm{N}$ & 22 & 22 & 22 & 22 & 22 \\
\hline \multirow{3}{*}{ Parking area } & $\begin{array}{l}\text { Pearson } \\
\text { Correlation }\end{array}$ & .354 & 1 & $.540^{* *}$ & .183 & $.449^{*}$ \\
\hline & Sig. (2-tailed) & .106 & & .009 & .416 & .036 \\
\hline & $\mathrm{N}$ & 22 & 22 & 22 & 22 & 22 \\
\hline \multirow{3}{*}{$\begin{array}{l}\text { Motor transport } \\
\text { networks area }\end{array}$} & $\begin{array}{l}\text { Pearson } \\
\text { Correlation }\end{array}$ & $.812^{* *}$ & $.540^{* *}$ & 1 & $.647^{* *}$ & $.909^{* *}$ \\
\hline & Sig. (2-tailed) & .000 & .009 & & .001 & .000 \\
\hline & $\mathrm{N}$ & 22 & 22 & 22 & 22 & 22 \\
\hline \multirow{3}{*}{ Trips time } & $\begin{array}{l}\text { Pearson } \\
\text { Correlation }\end{array}$ & $.647^{* *}$ & 183 & $.647^{* *}$ & 1 & $.567^{* *}$ \\
\hline & Sig. (2-tailed) & .001 & .416 & .001 & & .006 \\
\hline & $\mathrm{N}$ & 22 & 22 & 22 & 22 & 22 \\
\hline \multirow{3}{*}{ Trips speed } & $\begin{array}{l}\text { Pearson } \\
\text { Correlation }\end{array}$ & $.716^{* *}$ & $.449^{*}$ & $.909^{* *}$ & $.567^{* *}$ & 1 \\
\hline & Sig. (2-tailed) & .000 & .036 & .000 & .006 & \\
\hline & $\mathrm{N}$ & 22 & 22 & 22 & 22 & 22 \\
\hline
\end{tabular}

Note. ${ }^{* *}$. Correlation is significant at the 0.01 level (2-tailed). ${ }^{*}$. Correlation is significant at the 0.05 level (2-tailed).

Source: Authors' work. 


\subsection{Land Use}

The region's settlement pattern has represented the lifestyle preferred by most Tehran families in the past few decades. Pearson Correlation among different types of urban land uses as mixed land use index is shown in table 4. Here, significant correlation among different types of land uses in all districts means land use mix, but insignificant correlation means low mix in urban land uses. These findings indicate that Tehran's development pattern results in low mix (or described differently, large separations between different land use types, such as housing and commercial services), which increases travel distances, mobility, social seclusion and automobile dependency.

Table 4. Correlations between land-uses types in Tehran regions

\begin{tabular}{llllllll}
\hline & & Residential & Industrial & Commercial & Ministerial & Greenland & Educational \\
\hline \multirow{5}{*}{ Residential } & Pearson Correlation & 1 & -.295 & $.607^{* *}$ & -.332 & .052 & $.638^{* *}$ \\
& Sig. (2-tailed) & & .182 & .003 & .131 & .817 & .001 \\
& $\mathrm{~N}$ & 22 & 22 & 22 & 22 & 22 & 22 \\
\hline \multirow{3}{*}{ Industrial } & Pearson Correlation & -.295 & 1 & .111 & .226 & .226 & .036 \\
& Sig. (2-tailed) & .182 & & .624 & .313 & .313 & .875 \\
& $\mathrm{~N}$ & 22 & 22 & 22 & 22 & 22 & 22 \\
\hline \multirow{5}{*}{ Commercial } & Pearson Correlation & $.607^{* *}$ & .111 & 1 & -.332 & -.332 & $.449^{*}$ \\
& Sig. (2-tailed) & .003 & .624 & & .131 & .131 & .036 \\
& $\mathrm{~N}$ & 22 & 22 & 22 & 22 & 22 & 22 \\
\hline \multirow{5}{*}{ Ministerial } & Pearson Correlation & -.332 & .226 & -.332 & 1 & .248 & -.169 \\
& Sig. (2-tailed) & .131 & .313 & .131 & & .266 & .453 \\
& $\mathrm{~N}$ & 22 & 22 & 22 & 22 & 22 & 22 \\
\hline \multirow{5}{*}{ Greenland } & Pearson Correlation & .052 & .226 & -.332 & .248 & 1 & .017 \\
& Sig. (2-tailed) & .817 & .313 & .131 & .266 & & .941 \\
& $\mathrm{~N}$ & 22 & 22 & 22 & 22 & 22 & 22 \\
\hline \multirow{6}{*}{ Educational } & Sig. (2-tailed) & .001 & .875 & .036 & .453 & .941 & \\
& $\mathrm{~N}$ & 22 & 22 & 22 & 22 & 22 & 22 \\
\hline
\end{tabular}

Note. ${ }^{* *}$. Correlation is significant at the 0.01 level (2-tailed). ${ }^{*}$. Correlation is significant at the 0.05 level (2-tailed).

Source: Authors' work.

\subsection{Mobility Condition by Drawing on Geographical Distribution}

The geographical distribution of mobility condition in all districts of Tehran is shown in the following figure in such a manner that moving from central business districts (CBDs) toward peripheral districts; one can see more motor transport network area, parking area, accident rates and automobile ownership rate. In contrast, moving from peripheral districts toward CBDs, one can see more use of public transportation and more non-motor transportation/walking (Figure 9). 


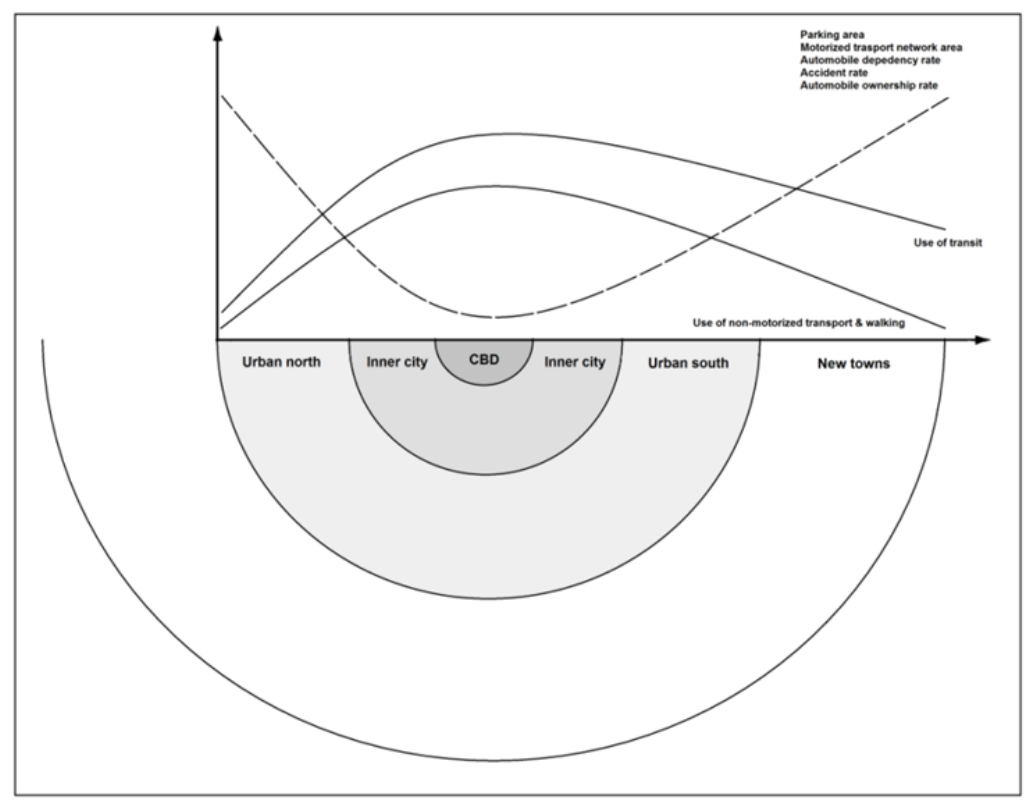

Figure 9. Mobility condition in Tehran urban region by drawing on geographical distribution

Source: Authors' work.

\section{Estimate of Urban growth quality}

According to conceptual framework in this article, the geographical distribution of population and land use determines the location of activities. The need for interaction arises as a consequence of the spatial separation between population and land-use activities. The transport system creates opportunities for interaction or mobility, which can be measured as accessibility. The distribution of accessibility in urban space, over time, co-determines location decisions and so results in changes in the urban growth quality.

According to results of table 6 , Tehran city have moved toward a sprawl quality more than compact quality. But it should be noted that the overall growth determined by increasing in city population.

Table 5. Tehran's urban growth quality base on urban growth indexes

\begin{tabular}{|c|c|c|c|c|c|}
\hline Index & Gini coefficient & $\begin{array}{c}\text { Entropy } \\
\text { coefficient }\end{array}$ & Shannon entropy & Holdren model & TOD index \\
\hline Formula & $\operatorname{Gini}=\sum_{i=1}^{N}\left|x_{i}-y_{i}\right|$ & $\begin{array}{l}H=-\sum P_{i} \operatorname{Ln} P_{i} \\
G=\frac{H}{\operatorname{LnK}}\end{array}$ & $H=-\sum_{i=1}^{n} P_{i} * \operatorname{Ln}\left(P_{i}\right)$ & $\begin{array}{l}a=\frac{A}{P} \\
A=P \times a \\
A+\Delta A \\
=(P+\Delta P) \\
\times(a \times \Delta a) \\
\frac{\Delta A}{A} \\
=\frac{\Delta P}{P}+\frac{\Delta a}{a}+\left(\frac{\Delta P}{P}\right) \\
\times\left(\frac{\Delta a}{a}\right) \\
g_{p}+g_{a}=g_{A}\end{array}$ & $T O D=\sum_{i=1}^{N}\left|x_{i}-y_{i}\right|$ \\
\hline
\end{tabular}




\begin{tabular}{|c|c|c|c|c|c|}
\hline & & & & $\begin{array}{l}g_{p}=\left(\frac{1}{t}\right) \operatorname{Ln}\left(\frac{p_{t}}{p_{0}}\right) \\
g_{A}=\left(\frac{1}{t}\right) \operatorname{Ln}\left(\frac{A_{t}}{A_{0}}\right) \\
g_{a}=\left(\frac{1}{t}\right) \operatorname{Ln}\left(\frac{a_{t}}{a_{0}}\right) \\
\operatorname{Ln} \frac{\Delta p}{p}+\operatorname{Ln} \frac{\Delta a}{a} \\
=\frac{\Delta A}{A}\end{array}$ & \\
\hline Description & $\begin{array}{l}\text { of zero(equality) } \\
\text { to } \\
\text { one(inequality) } \\
\text { in population } \\
\text { distribution }\end{array}$ & $\begin{array}{l}\text { of zero(balance) } \\
\text { to } \\
\text { one(unbalance) } \\
\text { in population } \\
\text { distribution }\end{array}$ & $\begin{array}{l}\text { of zero(compact) } \\
\text { to maximum of } \\
\text { value (sprawl) } \\
\text { in built area }\end{array}$ & $\begin{array}{l}\text { causes of being } \\
\text { compact or } \\
\text { being sprawl in } \\
\text { urban growth }\end{array}$ & $\begin{array}{l}\text { of zero(high } \\
\text { index) to } \\
\text { one(low index) } \\
\text { in } \\
\text { transit-oriented } \\
\text { development }\end{array}$ \\
\hline Results & 0.56 & 0.83 & 2.95 & $\begin{array}{c}0.83 \% \text { because } \\
\text { of population } \\
\text { increase) \& } \\
0.17 \% \text { because } \\
\text { of sprawl growth }\end{array}$ & 0.35 \\
\hline
\end{tabular}

Source: Authors' work.

\section{Survey of Public Values and Attitudes}

According to the questionnaire survey on individual tendency to car ownership/use, preferences for travel mode choice, preference for living in sprawl/smart neighborhoods in samples ( $\mathrm{n}=300$; samples: $50 \%$ female/ $50 \%$ male; from 20-65 years old); one can say that travel behavior /demand and choose locations/neighborhoods in respondents is briefly toward car ownership/use and living in sprawl neighborhoods (Figure 10).

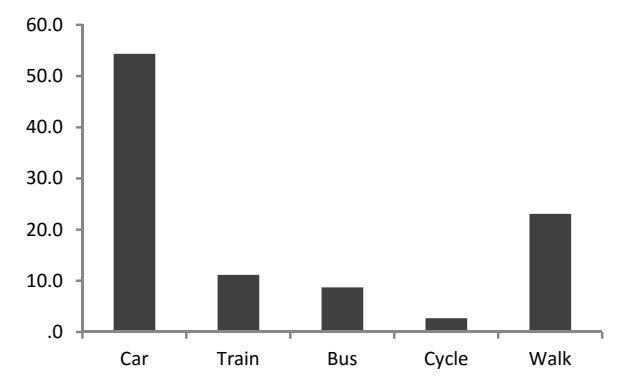

Preferences for travel mode choice (\%)

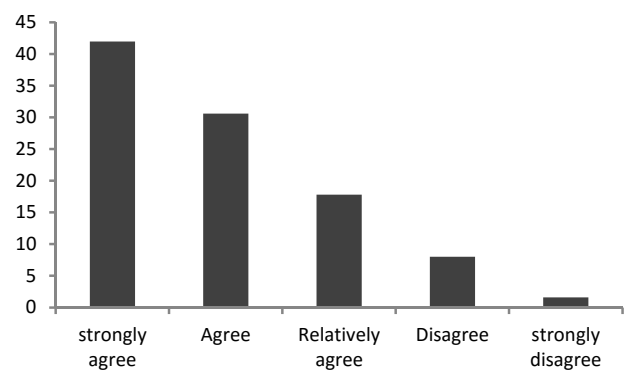

Tendency to car ownership and use (\%) 

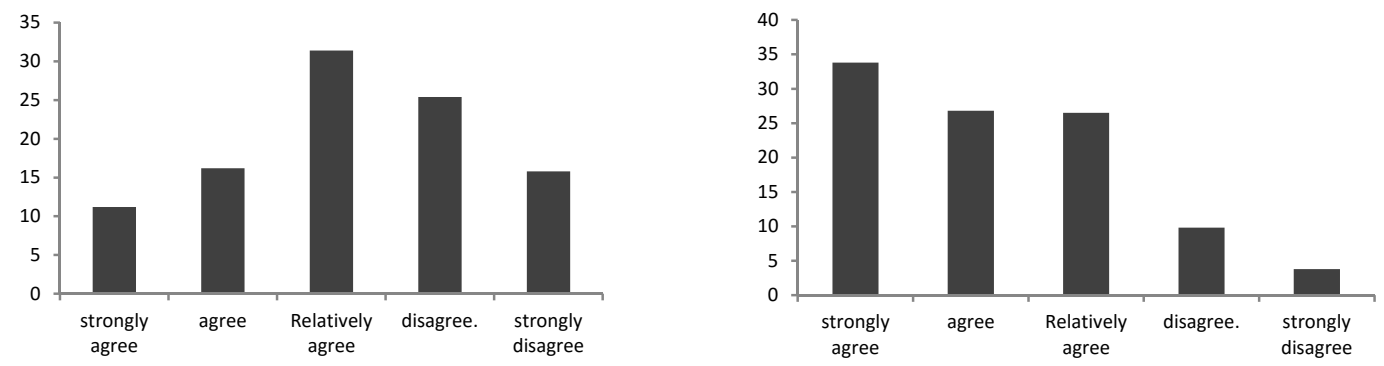

Preference for living in smart neighborhoods (\%) Preference for living in sprawl neighborhoods (\%)

Figure 10. Public Values and Attitudes

Source: Authors' work.

\section{Measuring of Land Use factors Impacts on VMT}

During past half century, transportation planners have mostly used traffic models for assessing demands and the effects of changes in transport systems. Those models use land use factors as an output. However, they are not sensitive to many land use factors emphasized in the current study (Frank and Pivo 1994; USEPA 2002; Hunt, 2001). During past decades many attempts have been made to improve these models in order to better evaluate how land use factors will affect future travel activity (Cervero and Kockelman, 1997; Rosenbaum and Koenig, 1997; Buch and Hickman, 1999; Cambridge Systematic, Inc. 1994; Dunphy and Fisher, 1996; Ewing and DeAnna and Li, 1996; Frank and Pivo, 199; USEPA, 2002). Many studies indicate that urban growth structural variables (i.e., density, diversity, design, destination accessibility, and distance to transit) have statistically significant influence on travel behavior (e.g., Aditjandra, Mulley \& Nelson 2013, Grunfelder \& Nielsen 2012, Gim 2013, Handy, Cao \& Mokhtarian 2005, Meurs \& Haaijer 2001, Næss 2013).

Here, we have used an equation for definition and then estimating the effects of changes in land use and urban design on travel demand (equation 1). It uses the extent of inclination of some factors including Density, Diversity, Design and Destinations depending on the features of built environment, neighborhood units, regional access and the amount of produced trips in a neighborhood unit. Those factors are used (for example in econometrics) for calculating the percentage of changes in total Vehicle Trips (VT) and VMT as a result of different land uses and urban designs.

$$
\text { Travel Demand }=\text { Density }+ \text { Diversity }+ \text { Design }+ \text { Destinations }
$$

- Density $=$ Percent Change in [(Population + Employment $)$ per hectare $]$

- Diversity $=$ Percent Change in $\{1-[\mathrm{ABS}(\mathrm{b} *$ population - employment $) /(\mathrm{b} *$ population + employment $)]\}$

- where: $\mathrm{b}=$ regional employment / regional population

- $\quad$ Design $=$ Percent Change in Design Index

- Design Index $=0.0195 *$ street network density $+1.18 *$ sidewalk completeness $+3.63 *$ route directness

where:

$0.0195=$ coefficient applied to street network density, expressing the relative weighting of this variable relative to the other variables in the Design Index formula,

street network density $=$ length of street in meter/area of neighborhood in hectares

$1.18=$ coefficient applied to sidewalk completeness, expressing the relative weighting of this variable relative to the other variables in the Design Index formula,

sidewalk completeness $=$ length of sidewalk/length of public street frontage

3.63 = coefficient applied to route directness, expressing the relative weighting of this variable relative to the other variables in the Design Index formula,

route directness $=$ average airline distance to center/average road distance to center

Destinations (accessibility) = Percent Change in Gravity Model denominator for study TAZs "I": $\operatorname{Sum}[$ Attractions $(\mathrm{j}) *$ Travel Impedance $(\mathrm{i}, \mathrm{j})]$ for all regional TAZs “ $\mathrm{j}$ ” 


$$
\begin{aligned}
\mathrm{y}_{\text {vehicle trips }} & =\left(-0.043 * \mathrm{x}_{\mathrm{d} 1}\right)+\left(-0.051 * \mathrm{x}_{\mathrm{d} 2}\right)+\left(-0.031 * \mathrm{x}_{\mathrm{d} 3}\right)+\left(-0.036 * \mathrm{x}_{\mathrm{d} 4}\right) \\
\mathrm{y}_{\text {vehicle miles traveled }} & =\left(-0.035 * \mathrm{x}_{\mathrm{d} 1}\right)+\left(-0.032 * \mathrm{x}_{\mathrm{d} 2}\right)+\left(-0.039 * \mathrm{x}_{\mathrm{d} 3}\right)+\left(-0.204 * \mathrm{x}_{\mathrm{d} 4}\right)
\end{aligned}
$$

After preparing required data in this regard (table 6), the estimation of different factors of density, diversity, design and destination could be done (table 7).

Table 6. Basic data and Study Parameters

\begin{tabular}{lll}
\hline & Parameters & Value \\
\hline 1 & Study Area: & \\
\hline 1.1 & Hectare & 75182 \\
\hline 2 & Region Demographics: & 12183491 \\
\hline 2.1 & Population & 3511175 \\
2.2 & Employment & \\
\hline 3 & Tehran Base Conditions in 2015: & 8402538 \\
\hline 3.1 & Population: & 2427845 \\
3.2 & Employment: & 18.6 \\
3.3 & Street network density: & $55 \%$ \\
3.4 & Sidewalk completeness: & 50 \\
3.5 & Pedestrian route directness: & 37.5 mean min. \\
3.6 & Accessibility: & $11.25 \mathrm{k}$ \\
3.7 & HB VMT/capita/day: & 9693997 \\
\hline 4 & Tehran Alternative Conditions in 10 years later $(2025):$ \\
\hline 4.1 & Population: & 3586778 \\
4.2 & Employment: & 20.46 \\
4.3 & Street network density: & $66 \%$ \\
4.4 & Sidewalk completeness: & 0.60 \\
4.5 & Pedestrian route directness: & 33.75 mean min. \\
4.6 & Accessibility: & \\
\hline
\end{tabular}

Source: Authors' work with base data source from Tehran Comprehensive Transportation and Traffic Co.: 2015; http://trafficstudy.tehran.ir \& Statistical Center of Iran http://www.amar.org.ir/english

Regarding to the changes in four indexes of "density", "diversity", "design" and "accessibility" in perspective of 2025, their effects on VMT calculated above, one can say that the total VMT per capita will decrease form 11.45 $\mathrm{km}$ in 2015 to $7.84 \mathrm{~km}$ in 2025 in daily basis.

\begin{tabular}{|c|c|c|c|c|}
\hline \multirow{2}{*}{ DENSITY } & Base Density & $\begin{array}{l}\text { Alternative } \\
\text { Density }\end{array}$ & Density Change & $\begin{array}{l}\text { HB VMT Change From } \\
\text { Density Change }\end{array}$ \\
\hline & $\begin{array}{l}111 \text { persons/ } \\
\text { Hectare }\end{array}$ & $\begin{array}{l}129 \text { persons/ } \\
\text { Hectare }\end{array}$ & $16 \%$ & $\begin{array}{lll}-0.56 \% & \text { HB } & \text { VMT } \\
\text { decrease } & & \\
\end{array}$ \\
\hline \multirow[t]{2}{*}{ DIVERSITY } & Base Diversity & $\begin{array}{l}\text { Alternative } \\
\text { Diversity }\end{array}$ & Diversity Change & $\begin{array}{l}\text { HB VMT Change From } \\
\text { Diversity Change }\end{array}$ \\
\hline & 0.57 & 0.87 & $52 \%$ & $\begin{array}{lll}-1.66 \% & \text { HB } & \text { VMT } \\
\text { decrease } & & \\
\end{array}$ \\
\hline \multirow{2}{*}{$D E S I G N$} & Base Design & $\begin{array}{l}\text { Alternative } \\
\text { Design }\end{array}$ & Design Change & $\begin{array}{l}\text { HB VMT Change From } \\
\text { Design Change }\end{array}$ \\
\hline & 2.8267 & 3.35577 & $18 \%$ & $\begin{array}{lll}-0.70 \% & \text { HB } & \text { VMT } \\
\text { decrease } & & \\
\end{array}$ \\
\hline \multirow[t]{2}{*}{ DESTINATIONS } & Base Accessibility & $\begin{array}{l}\text { Alternative } \\
\text { Accessibility }\end{array}$ & $\begin{array}{l}\text { Accessibility } \\
\text { Change }\end{array}$ & $\begin{array}{l}\text { HB VMT Change From } \\
\text { Accessibility Change }\end{array}$ \\
\hline & $34.76 \mathrm{~min}$ & $30 \mathrm{~min}$ & $13.7 \%$ & $\begin{array}{ll}-2.8 \% & \text { HB } \\
\text { decrease } & \\
\end{array}$ \\
\hline CUMULATIVE VMT & & & & Total of $\mathrm{HB}$ \\
\hline
\end{tabular}

Table 7. Measuring of Land Use factors Impacts on VMT 


\begin{tabular}{|c|c|c|c|c|}
\hline CHANGE & & & & changes \\
\hline & & & & -5.72 \\
\hline & $\begin{array}{l}\text { Base case HB } \\
\text { VMT/capita/day }\end{array}$ & $\%$ reduction & $\begin{array}{l}\text { VMT/capita/day } \\
\text { reduction }\end{array}$ & $\begin{array}{l}\text { Alternate case } \\
\text { VMT/capita/day }\end{array}$ \\
\hline & 11.25 & 0.0572 & 0.64 & 7.84 \\
\hline
\end{tabular}

Source: Authors' work.

The reduction in daily VMT per capita has deep consequences on urban growth patterns. Such reductions can help decease various negative consequences caused by motor vehicle travel and the road and parking facilities it requires, including land consumption, highway construction, traffic congestion, fuel and energy consumption, air pollution, noise, vehicle-oriented development, social segregation, and other problems caused by urban sprawl

\section{Concluding Remarks}

Like many cities around the world, the Tehran metropolitan region is growing rapidly. How it grows, including neighborhood density, diversity (mix) and roadway network design, can have many economic, social and environmental impacts. This study uses an integrated land use and transportation model to investigate how various land use factors affect travel activity, and therefore various transport costs. This research contributes to our understanding of urban development impacts, which has practical implications for policy and planning decisions.

This research indicates that Metropolitan Tehran's growth does not enjoy balanced and sustainable conditions. The results support the Tehran's Comprehensive Plan's goals to apply growth management in order to create more accessible and multi-modal communities in order to reduce vehicle travel and associated costs. However, consumer surveys indicate that a significant portion of households currently prefer to live in more suburban, and therefore more automobile-dependent, neighborhoods. Policies must respond to these preferences, for example, by creating more walkable and transit-oriented suburbs, and to find incentives that would encourage more middle-income households to choose accessible and multi-modal urban neighborhoods over sprawled locations.

Robust methodologies for measuring accessibility, the key concept that links land-use and transportation, are needed to adequately evaluate the effects of land-use policies on transportation and vice versa. Finally, the potential impacts of policy responses on urban location and mobility decisions, as opposed to the known impacts of individual lifestyles and preferences, and the implications for modeling techniques can be an interesting line of inquiry in future research on Tehran city.

\section{References}

Acheampong, R. A., \& Silva, E. A. (2015). Land use-transport interaction modeling: A review of the literature and future research directions, The Journal of Transport and Land use, 6(3), 11-38. Retrieved from http://jtlu.org

Aditjandra, P. T., Mulley, C., \& Nelson, J. D. (2013). The influence of neighborhood design on travel behavior: Empirical evidence from North East England. Transport Policy, 26, 54-65.

Albeverio, S., Andrey, D., Giordano, P., \& Vancheri, A. (Eds.) (2008). The Dynamics of Complex Urban Systems: An Interdisciplinary Approach. Springer, Berlin.

Allen, P. M. (1997). Cities and Regions as Self-organizing Systems: Models of Complexity. Taylor and Francis, London.

Alonso, W. (1964). Location and land use. Toward a general theory of land rent. Cambridge, Massachusetts: Harvard University Press.

Anas, A. (1998). NYMTC Transportation Models and Data Initiative: The NYMTC Land Use Model Alex Anas \& Associates, Williamsville, NY.

Anderstig, C., \& Mattsson, L. G. (1991). An integrated model of residential and employment location in a metropolitan region. Papers in Regional Science, 70, 167-84.

Anderstig, C., Mattsson, L. G. (1998). Modelling land-use and transport interaction: evaluations and policy analysis. In: Network Infrastructure and the Urban Environment: Recent Advances in Land-Use/Transportation Modelling (L. Lundqvist, L.-G. Mattsson, T.J. Kim, Eds.), 308-328. Springer, Berlin/Heidelberg/New York.

Batty, M. (2007). Cities and Complexity: Understanding Cities with Cellular Automata, Agent-Based Models, 
and Fractals. Cambridge, MA, and London: The MIT press.

Batty, M. (2008). Fifty years of urban modeling: macro-statics to micro-dynamics. In: S. Albeverio, D. Andrey, P. Giordano \& A. Vancheri (Eds.), The Dynamics of Complex Urban Systems: An Interdisciplinary Approach. Springer, Berlin, 1-19.

Bauer, K. W. (2010) City Planning for civil Engineers. Environmental Engineers and Surveyors. CRC Press, Taylor \& Francis.

Bhatta, B. (2010). Analysis of Urban Growth and Sprawl from Remote Sensing Data, New York. Springer.

Black, W. R. (2003). Transportation: A Geographical Analysis. New York: Guilford Press.

Black, W. R. (2010). Sustainable transportation: problems and solutions, The Guilford Press. New York.

Boyce, D. E., LeBlanc, L. J., Chon, K. S., Lee, Y. L., \& Lin, K. T. (1981). Combined Models of Location,Destination, Mode and Route Choice: A Unified Approach Using Nested Entropy Constraints Publication No. 3. Transportation Planning Group, Department of Civil Engineering, University of Illinois, Urbana, IL.

Bruegmann, R. (2005). Sprawl: A compact history, The University of Chicago Press.

Buch, M., \& Hickman, M. (1999). The Link Between Land-use and Transit: Recent Experience in Dallas, paper presented at the 78th Annual Meeting, Transportation Research Board, Washington, D.C.

Buel, R. A. (1972). Dead End: The Automobile in Mass Transportation, New York: Prentice Hall.

Burchell, R., Downs, A., McCann, B., \& Mukherji, S. (2005). Sprawl Costs: Economic Impacts of Unchecked Development, Island Press. Retrieved from http://www.islandpress.org

Caindec, E. K., \& Prastacos, P. (1995). A Description of POLIS. The Projective Optimization Land Use Information System Working Paper, 95-1. Association of Bay Area Governments, Oakland.

Calthorpe, P. (1993). The Next American Metropolis: Ecology, Community, and the American ream. New York: Princeton Architectural Press.

Calthorpe, P., \& Fulton, W. (2001). The Regional City: Planning for the End of Sprawl. Washington, DC: Island Press.

Cambridge Systematics (1994). The Effects of Land Use and Travel Demand Management Strategies on Commuting Behavior, Travel Model Improvement, USDOT. Retrieved from http://www.bts.gov

Cervero, R., \& Kara K. (1997), Travel Demand and the 3Ds: Density, Diversity, and Design. Transportation Research D, 2(3), September, 199-219.

Coppola, P., Ibeas, Á., dell'Olio, L., \& Cordera, R. (2013). LUTI model for the metropolitan area of Santander. Journal of Urban Planning and Development, 139(3), 153-165.

de la Barra, T. (1989). Integrated Land Use and Transport Modeling. Cambridge University Press, Cambridge.

Department for Transport, (2007). Manual for Streets. Thomas Telford Publishing.

Duany, A., Plater-Zyberk, E., \& Speck, J. (2000). Suburban Nation: The Rise of Sprawl and the Decline of the American Dream. North Point Press, New York.

Dunphy, R. T., \& Fisher, K. (1996) Transportation, Congestion, and Density: New Insights, Transportation Research Record 1552, pp. 89-96.

Ewing, R. S., \& Robert, C. (2010), Travel and the Built Environment: A Meta-Analysis. Journal of the American Planning Association, 76(3), 265-294. Retrieved from http://pdfserve.informaworld.com/287357_922131982.pdf

Ewing, R., DeAnna, M., \& Li, S. (1996). Land-use Impacts on Trip Generation Rates, Transportation Research Record 1518, pp. 1-7.

Farnaz, A., Iradj, F., \& Moeini, S. H. (Eds.) (2016). Urban Change in Iran: Stories of Rooted Histories and Ever-accelerating Developments. The Urban Book Series. Springer International Publishing Switzerland.

Frank, L. D. S., \& Pivo, G. (1994). Relationships Between Land-use and Travel Behavior in the Puget Sound Region, Washington State Department of Transportation, Seattle, pp. 9-37.

Frumkin, H., Frank, L., \& Jackson, R. (2004). Urban sprawl and public health: designing, planning, and building for healthy communities. Washington, DC. 
Gim, T. H. T. (2013). The relationships between land use measures and travel behavior: A meta-analytic approach. Transportation Planning and Technology, 36, 413-434.

Grant, J. (2006). Planning the Good Community; New Urbanism in Theory and Practice, Routledge.

Grunfelder, J., \& T. S. Nielsen. (2012). Commuting behavior and urban form: A longitudinal study of a polycentric urban region in Denmark. Geografisk Tidsskrift-Danish Journal of Geography, 112, 2-14.

Gudmundsson, H., Hall, R. F., Marsden, G., \& Zietsman, J. (2016). Sustainable Transportation: Indicators, Frameworks, and Performance Management, Springer-Verlag, Heidelberg Germany.

Haag, G. (1990). Master equations. In: Urban Dynamics. Designing an Integrated Model (C,S. Bertuglia, G. Leonardi, A. G. Wilson, Eds.), 69-83. Routledge, London/New York.

Handy, S., Cao, X., \& Mokhtarian, P. (2005). Correlation or causality between the built environment and travel behavior? Evidence from Northern California. Transportation Research Part D: Transport and Environment, 10, 427-444.

Hanson, S., \& Giuliano, G. (Eds.) (2004). The Geography of Urban Transportation (3rd edn.), New York: The Guilford Press.

Hayden, D. (2003). Building Suburbia: Green Fields and Urban Growth, 1820-2000. New York: Random House.

Hensher, D., \& Ton, T. (2001). TRESIS: A transportation, land use and environmental strategy impact simulator for urban areas. Paper presented at the 8th World Conference on Transport Research, Seoul.

Hunt, D. (2001). A Stated Preference Analysis of Sensitivities to Elements of Transportation and Urban Form, Transportation Research Board Annual Meeting. Retrieved from http://www.trb.org

Hunt, J. D., \& Abraham, J. E. (2003). Design and application of the PECAS land use modeling system. Paper presented at the 8th International Conference on Computers in Urban Panning and Urban Management, Sendai, Japan.

Hunt, J. D., \& Echenique, M. H. (1993). Experiences in the application of the MEPLAN framework for land use and transport interaction modeling. In: Proceedings of the 4th National Conference on the Application of Transportation Planning Methods, 723-754. Daytona Beach, FL.

Jacobs, J. (1961). The Death and Life of Great American Cities, New York: Vintage.

Jenks, M., \& Burgess, R. (2000). Compact Cities: Sustainable Urban Forms for Developing Countries. Spon Press.

Keats, J. (1958). Insolent Charioteers. Philadelphia: Lippincott.

Kim, T. J. (1989). Integrated Urban Systems Modeling: Theory and Applications. Kluwer, Dordrecht.

Kunstler, J. H. (1993). The Geography of Nowhere: The rise and decline of America's man-made landscape. New York: Simon and Schuster.

Landis, J. D. (1992). BASS II: A New Generation of Metropolitan Simulation Models. Working Paper 573 Institute of Urban and Regional Development, University of California, Berkeley,CA.

Leavitt, H. (1970). Superhighway-Superhoax Garden City, NY: Doubleday.

Litman. T. (2014). Analysis of Public Policies That Unintentionally Encourage and Subsidize Urban Sprawl, Victoria Transport Policy Institute (www.vtpi.org), LSE Cities (www.lsecities.net), for the Global Commission on the Economy and Climate. Retrieved from http://www.newclimateeconomy.net); at http://bit.ly/1EvGtIN

Mackett, R. L. (1983). The Leeds Integrated Land-Use Transport Model (LILT). Supplementary Report SR 805 Transport and Road Research Laboratory, Crowthorne, Berkshire.

Mackett, R. L. (1990). MASTER Model (Micro-Analytical Simulation of Transport, Employment and Residence). Report SR 237 Transport and Road Research Laboratory, . Crowthorne, Berkshire.

Martinez, F. J. (1991). Transport investments and land values interaction: the case of Santiago City. In: Proceedings of the PTRC Summer Annual Meeting, 45-58. PTRC, London.

Martinez, F. J. (1996). Analysis of urban environmental policies assisted by behavioural modelling. In: Transport, Land Use and the Environment (Y. Hayashi, J. Roy, Eds.), 233-257. Kluwer, Dordrecht 
Meurs, H., \& Haaijer, R. (2001). Spatial structure and mobility. Transportation Research Part D: Transport and Environment, 6, 429-446.

Miller, E. J., Kriger, D. S., Hunt, J. D., \& Badoe, D. A. (1998) Integrated Urban Models for Simulation of Transit and Land-Use Policies. Final Report, TCRP Project H-12. Joint Program of Transportation, University of Toronto, Toronto.

Mitchell, J. (1970). Big Yellow Taxi, in Bruegmann, Robert. (2005) Sprawl: a compact history, The University of Chicago Press.

Miyamoto, K., \& Udomsri, R. (1996). An analysis system for integrated policy measures regarding land use, transport and the environment in a metropolis. In: Transport, Land Use and the Environment (Y. Hayashi, J. Roy, Eds.), 259-280. Kluwer, Dordrecht.

Morris, D. E. (2005). It's a sprawl world after all, New Society Publishers.

Mumford, L. (1961). The city in history: Its origins, its transformations, and its prospects. New York: Harcourt, Brace \& World.

ODOT: Oregon Department of Transportation (2002). Retrieved from http://www.odot.state.or.us/tddtpau/modeling.html

Putman, S. H. (1983). Integrated Urban Models: Policy Analysis of Transportation and Land Use Pion, London. London: Pion.

Putman, S. H. (1991). Integrated Urban Models 2. New Research and Applications of Optimization and Dynamics. London: Pion.

Ricardo, D. (1821). On the Principles of Political Economy and Taxation. London: Murray.

Rodrigue, J. P., Claude, C., \& Brian, S. (2006). The Geography of Transport Systems. Routledge.

Rosenbaum A. S., \& Brett, E. K. (1997). Evaluation of Modeling Tools for Assessing Land Use Policies and Strategies, Office of Mobile Sources, USEPA Retrieved from http://www.epa.gov

Samet, R. H. (2013). Complexity, the science of cities and long-range futures. Futures 47: 49-58.

Schiller, P. L., Bruun, E. C., \& Kenworthy, J. R. (2010). An introduction to sustainable transportation :policy, planning and implementation. Earthscan.

Schneider, R. R. (1972). Autokind vs. Mankind. New York: Schocken Books.

Simmonds, D. (2001). The objectives and design of a new land-use modelling package: DELTA In: Regional Science in Business (G.P. Clarke, M. Madden, Eds.), 159-188. Springer, Berlin/Heidelberg.

Smart Growth Network (SGN) (2015). This Is Smart Growth. Retrieved from $\mathrm{http}: / /$ www.epa.gov/smartgrowth/tisg.htm

SUMP (2013). Guidelines. Developing and Implementing a Sustainable Urban Mobility Plan. European Commission, Brussels.

Talen, E. (2005). New urbanism and American planning: The conflict of cultures, Routledge.

Taniguchi, E. (2015). City logistics for sustainable and liveable cities. In Green Logistics and Transportation: A Sustainable Supply Chain Perspective, Fahimia, B., Bell, M.G.H., Hensher, D. A. and Sarkis, J. (Eds.), Springer International Publishing Switzerland 49-60.

USEPA (2002). Smart Growth Index (SGI) Model, Version 2.0; Indicator Dictionary, U.S. Environmental Protection Agency Retrieved from http://www.epa.gov/livablecommunities/topics/sg_index.htm

Victoria Transport Policy Institute (VTPI). (2005). Sustainable transportation and TDM. Planning that balances economic, social and ecological objectives. TDM Encyclopedia. Retrieved from http://www.vtpi.org

von Thünen, J. H. (1826). Der Isolierte Staat (English translation by C. M. Wartenberg, edited by P. Hall, von Thünen's Isolated State, 1966. Oxford: Pergamon Press).

Waddell, P. (2002). UrbanSim: Modeling urban development for land use, transportation and environmental planning. Journal of the American Planning Association, 68, 297-314

Webster, F. V., Bly, P. H., \& Paulley, N. J. (Eds.) (1988). Urban Land-Use and Transport Interaction: Policies and Models. Report of the International Study Group on Land-Use/-Transport Interaction (ISGLUTI). Avebury, Aldershot. 
Wegener, M., \& Fürst, F. (1999) Land-Use Transport Interaction: State of the Art. Berichte aus dem Institut für Raumplanung 46. Institut für Raumplanung, Universität Dortmund, Dortmund. Retrieved from http://www.inro.tno.nl/ transland/Deliverable\%202a.pdf

Williams, I. W. (1994). A model of London and the South East Environment and Planning B: Planning and Design, 21, 535-539.

Williamson, T. (2010). Sprawl, justice, and citizenship: the civic costs of the American way of life, Published by Oxford University Press.

Wilson, A. G. (1997). Land use/transport interaction models - past and future. Journal of Transport Economics and Policy, 32, 3-23.

Wingo, L., J. (1961). Transportation and Urban Land. Washington, DC: Resources for the Future, Inc. Retrieved from http://en.tehran.ir: Tehran Municipality. (Accessed 15 January 2015).

\section{Copyrights}

Copyright for this article is retained by the author(s), with first publication rights granted to the journal.

This is an open-access article distributed under the terms and conditions of the Creative Commons Attribution license (http://creativecommons.org/licenses/by/3.0/). 